\title{
Néhány választott egyéni sportág jelenlegi helyzetének és versenyképességének elemzése Magyarországon
}

\section{T. MADARÁSZ}

Debreceni Egyetem, Gazdaságtudományi Kar, Vidékfejlesztés, Turizmus- és Sportmenedzsment Intézet, Sportgazdasági- és menedzsment Tanszék, madarasz.tamas@econ.unideb.hu

Absztrakt. Az elmúlt néhány évben, hazánkban a sport jelentősége megnövekedett. 2010-ben kiemelésre került 16 egyéni sportág, melyek kiemelt állami támogatásban részesülnek a 2013-2020 közötti időszakban. Jelen kutatásban a kijelölt sportágak közül négy szakágnak - kajak-kenu, öttusa, birkózás, cselgáncs - vizsgáltam a hazai helyzetét és versenyképességét. A sportágak versenyképességét a médiában elfoglalt szerepük alapján vizsgáltam, a Nemzetközi Olimpiai Bizottság (NOB) módszerének megfelelően. A NOB, illetve az ötkarikás játékok szervezőbizottsága (OCOG) a közvetítésekből befolyt összegeket szétosztja a sportágak között, támogatás gyanánt. Fontosnak érzem a sportágak versenyképességét vizsgálni, továbbá a nemzetközi jótapasztalatokat felhasználva később megoldást javasolni a nézettségi adatok növelésére. Ennek első lépcsője ez a kutatás, mely bemutatja a sportágak Magyarország-i helyzetét, feltárja azok különbségeit, és párhuzamot állít a hasonlóságok között.

Abstract. In the past few years, our country increased importance of sports. 2010 was highlighted in 16 individual sports, which receive state subsidies for the period 2013-2020. In this research we selected the four disciplines of sports - canoeing, modern pentathlon, wrestling, judo - I examined the domestic situation and competitiveness. The sports competitiveness investigated on the basis of their role in the media occupied, according to the method of the International Olympic Committee (IOC). The IOC and the Olympic Games Organising Committee (OCOG) mediation from the proceeds distributed to sports, by way of support. I think it is important to examine the competitiveness of sports, and international jótapasztalatokat used later to propose solutions to increase viewing figures. The first stage of this research, which shows the position of sports Hungary, explore their differences and draw parallels between the similarities.

\section{Bevezetés}

A sport társadalmi, gazdasági, kulturális, nemzeti identitást meghatározó tényező. Egyénileg az önmegvalósítás, a szabadidő kulturált eltöltésének eszköze, az egészségtudatos életvitel megtestesítője. Társadalmilag közösségformáló, sőt nemzeti összetartó erőt befolyásoló tényező. A sport gazdasági hatása is könnyen belátható, hiszen az egészséges életvitel nagyobb teherbírással, kevesebb munkahelyi hiányzással, és így kevesebb egészségbiztosítási kiadással is jár. A sport megnövekedett jelentőségét az is igazolja, hogy ezt a kormányzat is felismerte, és 2010 óta stratégiailag kiemelt ágazatként kezeli.

Az élsporton a csapatsportok és ezen belül a látványsportok, kiemelt támogatást kapnak, mind nemzetközi, mind hazai viszonylatban is. Az élsport egy másik szegmense, amiben igazi sport hungaricumok vannak, és 
amelyekben hagyományosan magyar sportsikerek születnek, úgy nemzetközileg, mint hazánkban nem biztos, hogy megkapja a szükséges támogatást. Hazai viszonylatban 2010-ben a Magyar kormányzat kiemelt 16 egyéni sportágat, amelyek az eredményességük alapján magasabb támogatásban részesülnek, az ,átlag” hazai sportágakhoz képest. Bár ez a támogatás óriási segítség minden érintett hazai sportszövetségnek, azonban ha az Olimpiai érmek számát, vagy a világbajnoki indulók és ott érmet elérő sportolók számát vesszük alapul, akkor ez a támogatás gyakorlatilag még mindig elenyésző, és csak arra elég, hogy a nemzetközi élmezőny második felében maradjunk.

Vizsgálatom célja feltárni az egyéni sportágak versenyképességét befolyásoló tényezőket, és ezek ismeretében egy modellt kidolgozni, amely segíthetne megőrizni, illetve javítani a magyar szempontból siker sportágakként nyilvántartott torna, öttusa, kajak-kenu, birkózás és cselgáncs versenyhelyzetét. A kérdés úgy is megfogalmazható, hogy ezen sportok esetében a sportszakmai sikeren túl mi biztosíthatja a társadalmi elismertséget illetve a gazdasági eredményességet?

\section{A sportágak helyzete Magyarországon}

Az öt sportág kiválasztásakor figyelembe vettem, hogy melyek azok a sportágak, amelyektől négyévente érmet, vagy érmeket várhatunk a nyári ötkarikás játékokon. A cselgáncs sportág nem tartozik a legjobbak közé, azonban a volt sportolói múltam miatt mégis kiindulási alapnak tekinteném. A többi négy sportág pedig az egyéni sportágak tekintetében igazi sporthungaricumoknak tekinthetőek. A kiválasztás során figyelembe vettem a sportági sajátosságokat, hogy hol lehet akár vizsgálat nélkül is szoros kapcsolódási pontokat felfedezni, hiszen ezáltal könnyebb közös nevezőt találni a szakágak között. Továbbá célom volt az, hogy egy alapvizsgálat elvégzése után, a nehezebb helyzetben lévő szakágakat helyezzem előtérbe.

A legsikeresebb magyar olimpiai sportágnak a vívás tekinthető, ahol 2013-ban az 1661 igazolt sportolóra 35 aranyérem jutott, azonban szeretném megjegyezni, hogy a sportág részletes vizsgálatára a jelenlegi kutatás nem tér ki. Magyarország a kajak-kenu éremszerző országok örökrangsorban a 3. helyet foglalja el. Haza viszonylatban is elmondható, hogy a kajak-kenu az olimpiákon megszerzett 77 éremmel, és a 485 olimpiai ponttal a 3. legeredményesebb olimpiai sportág hazánkban (1. táblázat). A veterán, a maraton és a sárkányhajó szakágak sportolói létszámait nem számolva 2013-ban 3605 fő igazolt sportolót tudhatott magának a szövetség. Ez a szám meglepően magas, ahhoz képest, hogy a sportág földrajzi adottságai nagyon kötöttek. Magyarországon Budapest, Győr, Paks, Szolnok és Szeged városa jelentik a nagyobb gócpontokat, ahol kajak-kenu sportegyesületek múködnek hazánkban.

\begin{tabular}{|l|l|l|l|l|l|l|l|l|l|}
\hline \multicolumn{2}{|l|}{ Sportág } & Arany & Ezüst & Bronz & $\begin{array}{l}\text { Összes } \\
\text { érem }\end{array}$ & IV. & V. & VI. & $\begin{array}{l}\text { Összes } \\
\text { pont }\end{array}$ \\
\hline 1. & Vívás & 35 & 22 & 26 & 83 & 25 & 25 & 14 & 598 \\
\hline 2. & Úszás & 25 & 23 & 18 & 66 & 24 & 24 & 17 & 499 \\
\hline 3. & Kajak-kenu & 22 & 29 & 26 & 77 & 14 & 14 & 12 & 485 \\
\hline
\end{tabular}




\begin{tabular}{|l|l|l|l|l|l|l|l|l|l|}
4. & Birkózás & 19 & 16 & 19 & 53 & 29 & 20 & 14 & 430 \\
\hline 5. & Torna & 15 & 11 & 14 & 40 & 13 & 11 & 15 & 292 \\
\hline 6. & Atlétika & 10 & 12 & 17 & 40 & 19 & 21 & 14 & 311 \\
\hline 7. & Ökölvívás & 10 & 2 & 8 & 20 & 2 & 15 & 1 & 149 \\
\hline 8. & Öttusa & 9 & 8 & 5 & 22 & 3 & 3 & 2 & 140 \\
\hline 9. & Vízilabda & 9 & 3 & 3 & 15 & 3 & 4 & 2 & 109 \\
\hline 10. & Sportlövészet & 7 & 3 & 7 & 17 & 4 & 7 & 11 & 129 \\
\hline$\ldots$ & & & & & & & & & \\
\hline 13. & Cselgáncs & 1 & 3 & 5 & 9 & 0 & 10 & 0 & 62 \\
\hline
\end{tabular}

1. táblázat: A Magyar sportágak rangsora az újkori olimpiák történetében 1896-2012

(Forrás: MOB adatai alapján saját szerkesztés)

Hazánk birkózói az olimpiai játékok örökrangsorában szintén kiemelkedő, negyedik helyen szerepel. Fontos azonban megjegyezni, hogy a toronymagasan vezető állam (Szovjetúnió) már nem létezik, így gyakorlatilag Magyarország a harmadik legeredményesebb birkózó nemzet a világon az ötkarikás játékok tekintetében. Kiemelkedő teljesítménynek számít, hogy míg a londoni olimpia évében 2372 , addig 2013-ban már 2856 igazolt sportolót tartott nyilván a szakág. A sportágfejlesztési stratégiában meghatározott feladatok és célok pontos végrehajtásának eredményeként, ez a szám 4816 fôre gyarapodott 2014-ben. A tervnek köszönhetően 2012-ben csak 275, míg 2014-ben már 2249 új igazolt sportolóval rendelkezett a Szövetség.[34] A birkózók által megszerzett 19 arany, 16 ezüst és 19 bronzérem, a negyedik legeredményesebb olimpiai sportágunkká teszi a szakágat. A sportág a 2012. évi londoni olimpia után komoly veszélybe került. Különböző sportágfejlesztési stratégiák alkalmazásával a szabályozók fejleszteni kívánták a birkózást, és ebbe a fejlődési folyamatba csatlakozott a Magyar Birkózó Szövetség is, és egy nagyon részletes tervet dolgoztak ki. E koncepció 3 fő projektben került meghatározásra. Elsősorban a verseny, és az élsport fejlesztése mellett, az úgynevezett szőnyegprogram segítségével az utánpótlás nevelés támogatását is célul tűzték ki (MBSZ, 2014).

Az öttusa az eddig megszerzett 9 arany, 8 ezüst és 5 bronzérem azonban a magyar olimpiai sportágak között csupán csak a 8. helyen található. Ennek ellenére elmondható, hogy hazánkban az öttusa az olimpiai játékok örökrangsorában az első helyen szerepel, mely figyelemre méltó az alacsony sportolói létszám tekintetében. A londoni olimpiai játékok évében összesen 621 igazolt sportolót számlált a sportág, melyből csupán 69 volt felnőttkorú.[38] Az öttusa sportágfejlesztési stratégiája alapján a várható sportolói létszám növekedést mutat, amely alapvetően szükséges a jó eredmények elérése érdekében. Problémát jelent a hazai sportágfejlesztésben a hazai létesítményhelyzet, mivel a magyar öttusa nem rendelkezik saját sportközponttal. Összetett sportág lévén e sportág eszköz és létesítmény (uszoda, lovarda, lőtér, fedett csarnok, futópálya, egyéb kiszolgáló helyiségek) igénye igen magas. A bérleti díjak jelentős költségtételt jelentenek a szövetség kiadásai között. Saját létesítmények esetén a 
költségek hosszútávon csökkenthetőek lehetnének, illetve az egyes létesítmények közötti utazási idő és energia is redukálható lenne, az egy területen lévő épületkomplexumok kialakításával.

Hazánk cselgáncsozói az olimpiai játékok örökrangsorában a huszonegyedik helyen szerepel. Joggal kérdezhetjük, hogy miért kerülhet bele az egyéni sikersportágakkal, sporthungaricumokkal foglalkozó kutatásba, egy olyan sportág amely a nemzetközi mezőnyben nincs benne a top húsz között. Mivel azonban Magyarországon sincs a legjobb 10 szakág között a sportág - 13. helyen található, a személyes érintettség miatt került be a vizsgálatba. A kevés olimpiai érem betudható a roppant alacsony igazolt sportolói létszámnak. A versenyengedéllyel rendelkező felnőtt és szenior sportolók száma 2013-ban csaknem 650 fő volt. A sportolói nyilvántartásból nem lehet megmondani, hogy ezek közül ki az, aki csak senior kategóriában indul versenyeken, bajnokságokon. A Nemzetközi Judo Szövetség (IJF) szabályzata határozza meg, hogy mikor és hogyan - milyen feltételekkel - indulhat valaki senior versenyeken. Persze nehezen beszélhetünk jól működő felnőtt versenysportról, megfelelő utánpótlásbázis nélkül. A versenyengedéllyel rendelkező fiatal sportolók száma szintén 2013-ban 1700 körüli volt. A különböző korosztályok egy-két évet foglalnak magukba, a felnőtt viszont 23 év fölött osztatlan évjáratokban versenyeznek.Az 1. ábrán az egyes sportágak gazdaságban betöltött szerepét mutatom be. Gyömörei (2012) Kotler (1992) alapján, a két tengelyen megjelöli az elérhető fogyasztók számát illetve a ténylegesen elért sportfogyasztók körét.

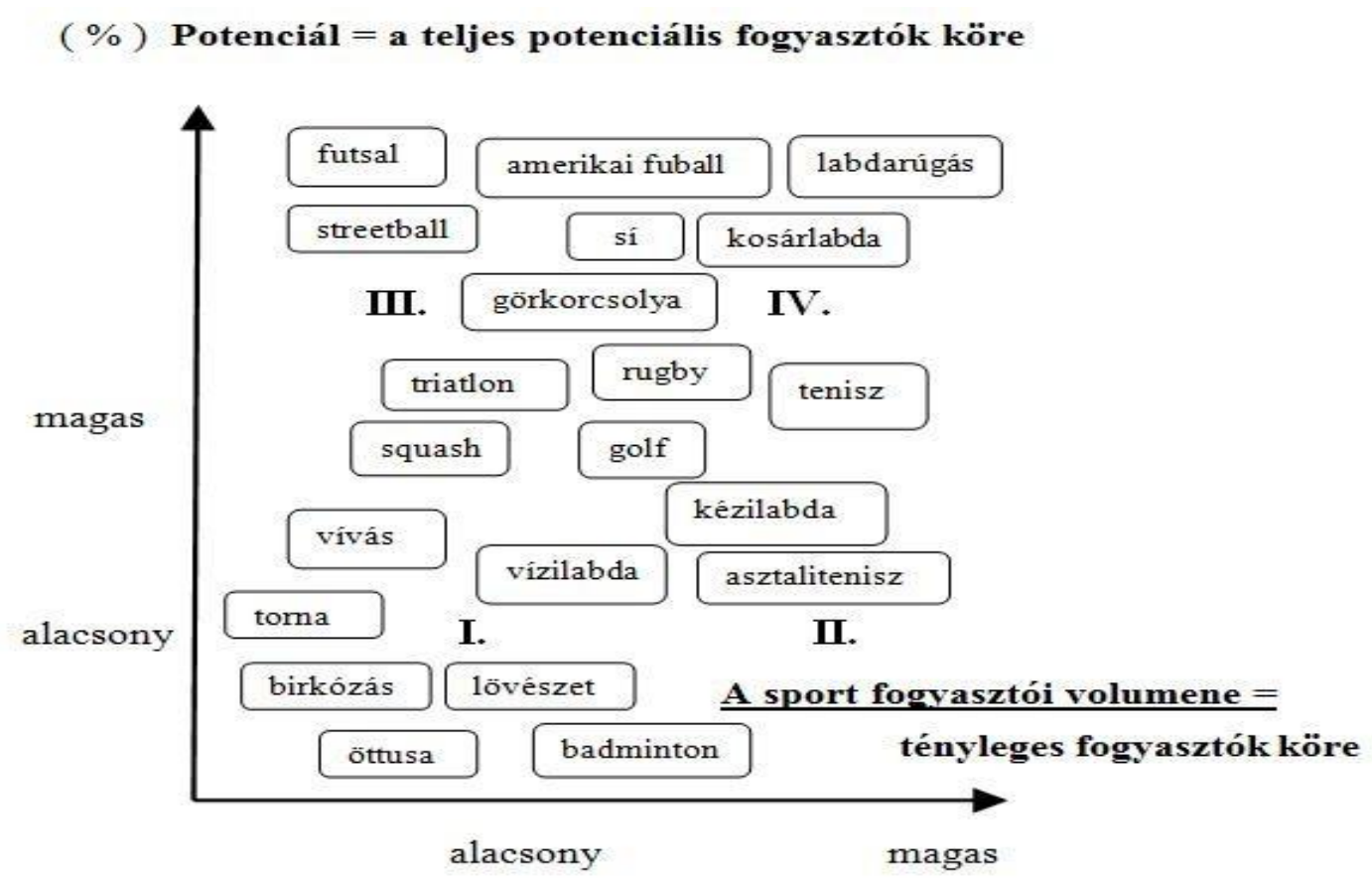

1. ábra: Az egyes sportágak gazdaságban betöltött szerepe

(Forrás: [27])

Az ábra jól szemlélteti, hogy a vizsgálatomban szereplő torna, birkózás illetve öttusa, mind a két tekintetben az alacsony kategóriában szerepel. Beszédes, hogy a Magyarországon szabadidősportként számon tartott görkorcsolya is jócskán megelőzi a sikersportágainkat. Ez ellen cselekedni kell! Az 1. ábrán látható, hogy azok a sportágak, amelyekkel foglalkozni szeretnék, eléggé le vannak maradva a 
népszerűbb csapatsportágaktól, így feltétlenül indokolt ezen sportágak versenyhelyzetének, gazdasági potenciáljának vizsgálata.

Az előzőekben említett sportágak az elmúlt évek eredményességének köszönhetően beválasztásra került a 16 kiemelt egyéni sportág közé, mely magasabb támogatási szintet eredményez. Simicskó István, az Emberi Erőforrások Minisztériumának sportért és ifjúságért felelős államtitkára 2013-ban kijelentette, hogy a 2014-2020-ig tartó időszakban az állam vezetése mintegy 135 milliárd forint támogatást ad az 2. táblázatban szereplő 16 sportágnak.

\begin{tabular}{|l|l|l|}
\hline A támogatott szövetségek és a támogatások összege & $2013(\mathrm{~m} \mathrm{Ft})$ & $\begin{array}{l}2014-2020 \quad \text { között } \\
\text { (Mrd Ft) }\end{array}$ \\
\hline Magyar Úszó Szövetség & 736,5 & 14,1 \\
\hline Magyar Birkózó Szövetség & 459,1 & 14,5 \\
\hline Magyar Kajak-Kenu Szövetség & 336,3 & 13,4 \\
\hline Magyar Atlétikai Szövetség & 314,5 & 18 \\
\hline Magyar Öttusa Szövetség & 304,9 & 9,5 \\
\hline Magyar Vívó Szövetség & 301,6 & 9,6 \\
\hline Magyar Torna Szövetség & 295,3 & 8,7 \\
\hline Magyar Ökölvívó Szakszövetség & 295,2 & 5,7 \\
\hline Magyar Cselgáncs Szövetség & 250,4 & 11 \\
\hline Magyar Országos Korcsolyázó Szövetség & 211,2 & 3 \\
\hline Magyar Röplabda Szövetség & 119,5 & 4,2 \\
\hline Magyar Tenisz Szövetség & 107,5 & 4,1 \\
\hline Magyar Kerékpársportok Országos Szövetsége & 94,4 & 2,8 \\
\hline Magyar Evezős Szövetség & 93,3 & 9,6 \\
\hline Magyar Sportlövők Szövetsége & 65,5 & 2,7 \\
\hline Magyar Asztalitenisz Szövetség & 43,7 & \\
\hline
\end{tabular}

2. táblázat: A kormány által kijelölt 16 egyéni sportág a kapott támogatási összegekkel

(Forrás: [56] alapján saját szerkesztés)

A kiemelt sportágak támogatási mértéke az igazolt sportolók számának a függvényében mutatkozik meg igazán, hiszen 1 főre vetítve hozható közös nevezőre a forrás. Az 1 főre jutó támogatási mutatót, azért számoltam ki, mert kutatási céljaim között szerepel, az egyéni sportágak pozicionálása a sportágak között, és ez az átlagérték alkalmas lehet a sportágak sorrendjének megállapítására a támogatási mértékük alapján. A 3. táblázat alapján látható, hogy az egy főre jutó támogatás a birkózás 
esetében átlag körülinek tekinthető az egyéni sikersportágainkhoz viszonyítva, melyet korábbi kutatásaim is igazolnak (Madarász, 2015). A táblázatban láthatjuk, hogy a sportágak támogatási összege jelentősnek tűnik, de ha jobban megnézzük, akkor tisztán kivehető, hogy például a Kajak-kenu sportág 69126 forintos támogatása nagyon csekély, ha azt igazolt sportolókra vetítjük.Ez a szám éves adat, tehát nem havonta kerül kifizetésre a szövetségeknek. Nagyon nagy a szórás a számok között, azonban fontos kiemelni, hogy reálisabb képet csak akkor kaphatunk, ha az egy főre jutó támogatások esetében figyelembe vesszük a sportágak eszközigényét is. A jelenlegi kutatás erre nem tért ki, azonban későbbi kutatásaimban egy komplex vizsgálat keretein belül vizsgálni kívánom.

\begin{tabular}{|l|l|l|l|l|l|}
\hline & Birkózás & Kajak-kenu & Vívás & Öttusa & Cselgáncs \\
\hline $\begin{array}{l}\text { Támogatás összege } \\
(\mathrm{eFt})\end{array}$ & 459100 & 336300 & 301600 & 304900 & 250400 \\
\hline $\begin{array}{l}\text { Igazolt sportolók } \\
\text { száma (fó) }\end{array}$ & 2856 & 4865 & 1661 & 621 & 2350 \\
\hline $\begin{array}{l}\text { Egy fóre jutó } \\
\text { támogatás (Ft/fó) }\end{array}$ & 160749 & 69126 & 181577 & 490982 & 106553 \\
\hline
\end{tabular}

3. táblázat: A vizsgált sportágak támogatási összegei egy före vetítve 2013-ban

(Forrás: Saját szerkesztés [34, 35, 36, 37, 38, 56] alapján, 2015)

\section{A versenyképesség fogalmi lehatárolása}

A versenyképesség napjaink egyik leggyakrabban használt fogalma.[21, 30]A legtöbb tudományág használja a versenyképesség fogalmát, de a használat, illetve értelmezés egyazon tudományágon belül is eltérő lehet. A verseny legáltalánosabb értelemben küzdelem egy kedvezőbb hely megszerzéséért, vagy adott cél elsőként való eléréséért.[42] A verseny számos területen értelmezhető. A versenyképesség elméletével és mérési lehetőségeivel számos kutató foglalkozik, még sincsen közöttük egyetértés a definíciót és a mutatószámokat illetően.[24] Bakács (2004) szerint a hazai és nemzetközi szakirodalomban jelentős véleménykülönbségek fedezhetőek fel. Bató (2003) is felhívja a figyelmet arra, hogy a versenyképességről szóló szakirodalom jelentős részét magáról a versenyképesség értelmezéséről szóló viták teszik ki, a vizsgálat tárgyát képező dimenziók meghatározása sem tiszta. A versenyképesség egy relatív mérőszám, fogalom.

Az elmúlt 30 évben kulcsfogalommá vált a versenyképesség, ahogy Lengyel (2000) idézi Begg (1999) szavait, miszerint: „...a versenyképesség javítása, ahogy az mindenki által köztudott, a gazdasági nirvánába vezető út”, utalva arra, hogy már-már „divatos közhellyé” vált a fogalom.

A sport területén már történtek versenyképességi kutatások, de ezek leginkább a csapatsportágakra vonatkoztak. Sterbenz (2011) szerint a közgazdasági irodalomban versenyképességen azt a képességet értik, amellyel az adott nemzet a globális verseny keretei között úgy tud értékesíteni termékeket és szolgáltatásokat, hogy közben termelési tényezőinek hozadék és állampolgárainak jóléte fenntartható módon növekszik. A sport területén jelen lévő versenyképességen Sterbenz Gulyás (2013) szerint az erőforrások olyan hatékony felhasználását értjük, amely fenntartható módon 
segíti a több és jobb minőségű sporttevékenység létezését. A versenyképességet a gazdasági felosztáshoz hasonlóan egyre magasabb szinteken értelmezhetjük: versenyzői, sportszervezeti, sportági, nemzeti szinteken.

András (2004) alapján különbséget kell tenni a sportpolitikában, sportadminisztrációban szinonimaként használt versenysport, professzionális sport, élsport és látványsport kifejezések között. Vizsgálatomban a hivatásos sport következő definíciójából indulok ki: A hivatásos sport piacán a középpontban a sportesemény áll, ez jelenti a piaci csereügylet tárgyát. Ezen a piacon a sportoló a kínálati oldal egyik kulcsszereplője: az esemény egyik létrehozója, munkaerő, akinek elsődleges célja a jövedelemszerzés, valamint a sporttal kapcsolatos előmenetel elérése.

Chikán (2008) a versenyt két vagy több szereplő egymással szembeni előnyszerzésre irányuló, adott szabályok közt zajló tevékenységeként definiálja. Ez a megközelítés a hivatásos sport területén is jól értelmezhető, amennyiben egy-egy bajnokság csapatai a pályán egymással versenyeznek a jobb sporteredményért (András - Kozma, 2014). András et all, (2000) felhívja azonban a figyelmet arra, hogy a sportgazdaságtanban kettősség van. A sportszakmai és gazdasági értelmezési síkok párhuzamosan definiálják a sportszervezetek célrendszerét, a jobb sporteredmény elérése mellett tehát a jobb pénzügyi eredmény elérése egyaránt cél.Már Chikán (2009) alapján András (2011) is megfogalmazta, hogy a sporteredményekben mért versenyen túl éles verseny figyelhető mega fogyasztók idő- és pénzráfordításáért, az üzleti szféra figyelméért és az államszervezeti-, jogi- és pénzügyi támogatásért. Szintén ezt támasztja alá Kozma - Kazainé (2013) miszerint a kiemelt érintettek figyelmének megszerzésére való törekvés integrált keretet adhat a pénzügyileg fenntartható sportsiker eléréséhez. András (2004) szerint az üzleti szférától eltérően a hivatásos sportban nem feltétlenül jár együtt a követelményeknek való erősebb megfeleléssel, illetve a versenyben való helytállás erősebb kényszerével, a túlélés veszélyeztetésével, melynek hátterében a hivatalos sport specialitásai állnak.A professzionális sport piacra jellemző, hogy hogy inkább munkának minősül a sportoló szempontjából. A sportoló célja a jövedelemszerzés, munkavállalóként jelenik meg munkaerőpiacon. A sport éppen ezért nem feltétlenül jár fizikai erőkifejtéssel a fogyasztó számára, mert a fogyasztó itt passzív szerepet tölt be, az élsportolók magas színvonalú sporttevékenységét élvezve jut hasznossághoz, kikapcsolódáshoz, élményhez.[44] András (2003) megfogalmazza, hogy alapvetően két részpiac különíthető el egy szabadidősport részpiac (rekreációs sport piaca), és a látványsport részpiac (professzionális sport piaca). Az előbb említett a szabadidőben végzett sporttevékenységet jelenti, mely esetben a sporttevékenységnek versenyeznie kell más szabadidős tevékenységekkel (televízió, mozi, színház stb.).[44]

A hivatásos sportban értelmezett versenyképesség is sokféle megközelítés és szempontrendszer alapján vizsgálható. A versenyképességnek alapvetően két dimenzióját különíthetjük el.[10] A nemzetgazdasági versenyképesség alapját jelentő domináns tényezőcsoportok típusa (erőforrások, befektetések, innovációk) tekinthető az egyik, míg a verseny kiterjedtsége, azaz a külgazdasági kapcsolatokban való részvétel mértéke (hazai, nemzetközi, regionális, vagy globális) a második dimenziónak.[19]Némethné (2010) szerint a sportterületet is vizsgálni kell makro- és mikroszintű, ex ante és ex post, külső és belső, input- és outputoldali hatótényezők és hatások mellett. A regionális versenyképességgel kapcsolatosan már megosztottabbak a kutatók, szerint beszélhetünk makro- vagy 
kisebb földrajzi régiókról.[21] A globalizáció hatására aregionális területfejlesztésben hosszú távú célként három prioritás fogalmazható meg: a gazdasági és társadalmi kohézió, a természeti erőforrások és a kulturális örökség megőrzése, valamint az európai térség kiegyensúlyozottabb versenyképessége. Ez olyan célhármast ad ki, amely kapcsolatba hozható a nagy sportesemények.[31] András (2004) felhívja a figyelmet, hogy a kormányzati politika jelentősen nagy szerepet kap a hivatásos sport a makrogazdasági versenyképesség szintjén, de kiemeli, hogy ez a vállalatok a hivatásos sport piacainak eltérő, de globális jellege miatt van ez így.[3] [6]

Ács (2007) szerint a sport területén versenyképesnek tekinthetünk egy területet, ha stratégiailag beágyazott gazdasági bázisa a piaci értéken megvásárolva optimálisan jól használja az erőforrásait, miközben tartós előnyöket szerez a nemzetközi piacon. Véleménye szerint azt a területet tekinthetjük a sport terén versenyképesnek, amely a rendelkezésre álló erőforrásokat olyan sporteredménnyé alakítja, mely alkalmas a folyamatosan fejlődő, magas igényeket támasztó világpiaci kereslet kielégítésére.

Palócz (2006) szintén az erőforrások fontosságára hívja fel a figyelmet. Véleménye szerint a humán tőkének jelentős szerepe van a fejlett és kevésbé fejlett országok közti nemzetgazdasági versenyképességbeli különbségeknek. Chikán - Czakó (2009) is egyetért azzal, hogy a humán tőke valamiképpen gazdasági közpolitikai eszközökkel befolyásolható. Csath (2010) is megfogalmazza, hogy a humán terület jelentősége folyamatosan nő, tevékenységével értéket termel. A makrogazdasági versenyképesség mellett egyéni és vállalati versenyképességet is javíthat a szabadidősport. Szabó (2012) kifejti, hogy az egészség, a sportolás szoros kölcsönhatásban áll a nemzetgazdasági versenyképességgel, amihez megfelelő gazdaság- és társadalompolitikát társítva egymást erősítő pozitív hatással bírnak. Szintén a társadalmi tőke fontosságára hívja fel a figyelmet Csath (2010) is. Véleménye szerint a gazdasági fejlődéshez és a növekedéshez erős társadalmi tőkére van szükség. Csath (2010) megfogalmazása szerint „... a társadalmi tőke azon erőforrásokat tartalmazza, amelyekhez az egyén vagy a cég személyes és üzleti kapcsolatai révén jut hozzá Ezek az erőforrások lehetnek ötletek, információk, pénz, üzleti lehetőségek, hatalom és befolyás, együttműködés, bizalom vagy pozitív imázs."

Balogh (2014) szerint a mind magasabb elvárások, a nemzeti, sokszor ideológiai háttér okozza, hogy új sportági technikai elemek, vagy akár új sportágak jelenhetnek meg, melyek új eszközöket, korszerűbb technológiai hátteret biztosítanak a sportiparnak. A rendkívül dinamikusan fejlődő sporttudománynak, mint alkalmazott tudományágnak, is szüksége van a versenyképesség fejlesztésére, leginkább a professzionális - élsport, de persze a szabadidősport szintjén is[40]. A sportiparág mára már a nemzeti össztermék jelentős elemévé lépett elő.[14] A látványsportnak is szükséges eleme a verseny, amely során a sportolók összemérik tudásukat, erejüket, képességeiket, készségeiket, ez adja a sportesemény élvezeti értékét.[44] A sportiparág mára már, a nemzeti össztermék jelentős elemévé lépett elő.[41] Elmondható tehát, hogy az innováció gyakorlatilag a versenyképesség növekedését jelenti. Ezáltal a versenyképes szervezet/sportág alkalmazkodni képes a folyamatosan változó környezethez, fel tudja venni a versenyt a piacra újonnan belépő szereplőkkel és képes a lehetőségeit mindig a legjobban kihasználni.[43] 
Ha a versenyképességet szeretnénk javítani, akkor gyakorlatilag innovációt, valamilyen újítást próbálunk keresni. Így van ez a sporton belül is. Ha a versenyképességgel foglalkozunk, alapvetően három definíciót érdemes figyelembe venni. Potori (2004) ugyan a mezőgazdasági ágazatok élet- és versenyképességét vizsgálta, de az általa említett eltartóképességet, életképességet és a versenyképességet bármely sportvállalkozás esetében is értelmezhető. Ezek a fogalmak egymáshoz kapcsolódóak, illetve egymás részterületei.

A fentiek alapján a sport területén értelmezve eltartóképesnek nevezhető az a sportág, mely a fix költségek kifizetése mellett nem képes akkora tartalékokat felhalmozni, amellyel a váratlan kiadásokat is fedezni tudja. Ezzel szemben életképesnek tekinthető az a sportág, amely a fix költségek kifizetése mellett, rendelkezik akkora felhalmozott tőkével, mellyel fel van készülve a váratlan kiadások okozta terhekre. Potori (2004) hiv. Lin (2002) vizsgálatai alapján azonban rámutat, hogy ha komparatív előnyt nem élvező ágazatban működik a vállalkozás, akkor megfelelő vezetés, tudás mellett is életképtelen lehet.[16]Versenyképesnek azt a sportágat tekinthetjük, mely a versenytársaival szemben - olimpiai vagy akár nem olimpiai sportágak - valamilyen versenyelőnyt képes kiharcolni, és azt hosszú távon meg is tudja tartani.

Vizsgálatomban a versenyképességet a sportág médiában elfoglalt szerepe alapján vizsgáltam, vagyis azt kutattam, hogy a 2012-es nyári játékokon, milyen mértékben volt jelen a sportág a médiában, mennyire volt versenyképes a nézőkért folytatott harcban.

Vizsgálatom érintettjeinek körét a sportpiac elemzésével jelölöm ki. A sport piacához András (2004) szerint a következők tartoznak: a fogyasztói piac, a játékos piac, a szponzori piac, a közvetítési jogok piaca és a Magyarországon igen csekély számban jelenlévő merchandising piac. András (2003) szerint, a fogyasztói piaconaz ember azért fizet, hogy mások sportolását megtekintse. Ezt a megtekintett sportolást mára hivatásos, professzionális sportolók végzik, és a kapott szolgáltatásba az alap- vagy magszolgáltatáson túl, úgynevezett kiegészítő szolgáltatások is beletartoznak. A csere tárgya a szabadidő olyan eltöltésének formája, ahol a szolgáltatás igénybevétele jellemzően valamilyen élménnyel, szórakozással párosul. A termék értékét mindezen túl mindenképp meghatározza az értékesítési csatorna minősége. A helyszínen történő szolgáltatás-igénybevétel esetén az elsősorban a sportlétesítmény, stadion kínálta lehetőségeken, míg a médián keresztüli fogyasztás esetén a média, mint transzformáló tényezőn múlik.[3]Sirgy (1982) szerint a sportfogyasztók specialitása a nagyfokú személyes azonosulás, melynek következtében a fogyasztók gyakran egyszerűnek, könnyen művelhetőnek találják a látottakat. A helyszíni fogyasztók belépőjegyet vagy bérletet váltva, a helyszínen közvetlenül élik át a sporteseménnyel kapcsolatos élményt. A médiafogyasztók számára a szórakozást egy médium, jellemzően a televízió közvetíti, mely Misovicz (1997) szerint napjainkra egyre inkább hozzáadott értékeket biztosít a televíziónézők számára.

András (2004) szerint a játékospiacegy speciális munkaerőpiac, ahol a szerződés tárgya alapvetően egy speciális vagyoni értékű személyi jog: a játékjog használatának meghatározott időtartamra vonatkozó átruházása. Olyan személyhez kötődő vagyoni értékű jog, mely a sportoló sporttevékenységéhez füződő fizikai és szellemi képességeinek összességét fejezi ki. Mint ilyen át nem ruházható, el nem adható, de a licence szerződéshez hasonlóan a sportvállalkozás (András (2003) vizsgálatában labdarúgó-vállalat) számára a játékjog használati joga átruházható. Ez csak a szerződés 
időtartamára történik, és ennek lejártát követően a használati jog ellenérték nélkül visszaszáll a sportolóra. A játékjog használati jogát a sportvállalat ideiglenesen vagy véglegesen más sportvállalatra ruházhatja a sportoló hozzájárulásával. Ebben az esetben az átadó vállalat térítésre, átigazolási díjra tarthat igényt. Kozma - Kynsburg (2000) meghatározták azokat a tényezőket, - érettség, önbizalom, felelősségtudat, alázat - melyek elősegíthetik, hogy a játékos minél nagyobb, pénzben is realizálható értéket jelentsen a játékospiacon. Mindezek alapján a sportolók játékjogának értékére ható tényezők egy része eleve meghatározott, másrészük irányított vagy hozzáadott jellemző.

A szponzori piac és a közvetítői jogok piacánakszereplői szorosan összefüggnek, hiszen egyik nélkül nincs a másik, de mégis érdemes a közvetítések piacával kezdeni, hiszen e nélkül nem létezhet sportszponzorálás. Sárközy (2002) alapján a közvetítés engedélyezésének joga, egy vagyoni értékű átruházhatatlan személyes természetű jog, mely eladhatatlan, adásvételi szerződés tárgya nem lehet. A jogbirtokos licence szerződéshez hasonlóan szerződés által a közvetítésre vonatkozóan használati jogot adhat a músorszolgáltatónak, mely ezáltal az immateriális jogot hasznosíthatja. A csere tárgyának legfőbb gyakorlati, üzleti értékét hordozó jellemzője, hogy reprodukálhatatlan, önmagában egyedi. Bourg (2000) szerint a kialkudott közvetítési díjban szignifikánsan csak a keresleti oldalon található résztvevők száma a meghatározó. Vannak olyan sportesemények, ahol a közvetítési jogok piacát a túlkínálat jellemzi. Ezekben az esetekben a közvetítési jogok árát egy piaci alku határozza meg. Urbán (1998) szerint a hosszú évekre megszerzett közvetítési jog és egy állandó műsorstruktúra nemcsak a pillanatnyi nézettséget emeli, hanem nézői szokások megváltoztatására, nézői hűség kialakítására is alkalmas. Ma már számos sportcsatorna múködik, és Whannel (1995) szerint a sport az általános csatornák műsoridejében is egyre nagyobb arányt képvisel. Urbán (1997) szerint Baumolkór hatás érvényesül az élőben sugárzott sport, mint televíziós műsorszám jogdíjaiban is. A hivatásos sport ráadásul olyan látványteremtés, ami a televízió képernyőjén is piacképes. A sport nagy tömegeket képernyő elé vonzó műsorszám jellegén túl ezzel is magyarázható, hogy az 1980-90-es években miért nőtt olyan viharosan az élő sportközvetítési jogok ára. Miután a sport egyike az olyan minőségi szórakoztató műsorszámoknak, melyek legfőbb eszközéül szolgálnak a közönségteremtésben, ez megemeli a sugárzáshoz szükséges jogdíjakat mind a hirdetésekből élő ingyenes, mind a fizetős televíziók esetén. Ez a közszolgálati televíziók műsorszerkezetére is kihat, hiszen így a magas jogdíjú műsorok piacáról kiszorulnak. Andreff (2008) szerint a televíziós közvetítések piaca határozottan globális piac. A nagyobb sporteseményeket 170-220 országban közvetítik. A cél nagyobb hallgatóság és/vagy nézettség elérése egy, a magasabb ár „bezsebelése” a hirdetőfelületekért.

A sportszponzorálás Kassay (1998) szerint gazdasági sikerek reményében megkötött, jogokat és kötelezettségeket jelentő, kétoldalú üzleti kapcsolat. A szponzorálás egyszerre képes szolgálni a vállalat reklámtevékenységét, illetve a sport eladását. Egy kétoldali üzleti kapcsolat, mely a sport egyik fontos bevételi forrását adja. Tóth (2013) szerint a szponzorálás platformo(ka)t szolgáltat arra, hogy célközönségünket, meglévő és új ügyfeleinket egyaránt, kölcsönösen előnyös partnerségen keresztül vonjunk be általuk szenvedélyesen szeretett tevékenységekbe, mérhető értéket teremtve. Berkes (2013) szerint a szponzoráció a patronálás modern megjelenési formája. De ezek a patrónusok nem mindig viselkednek önzetlen fillantrópként, mert a szponzoráció a szigorúan üzleti stratégia szerint múködő vállalatok esetében befektetés. Eredménye, haszna egyszerre szolgálja a vállalat marketing-, 
reklám-, PR céljait. A merchandisingpiacon Dénes (1998) szerint a sportvállalati védjegyek jogilag védett, engedélyezett forgalmazásáról van szó, mely logókkal, szimbólumokkal és megjelenésekkel (játékosok nevével, aláírásával, képével, stb.) ellátott termékek eladását foglalja magába. Végtelen válfajának tömeges és hatékony alkalmazására az 1980-90-es években került sor, jellemzően az üzleti élet reklámigényes területein.[3] Dénes (1998) szerint a merchandising vásárlásösztönző eszközként való felhasználása nem sporttalálmány, de az utóbbi években ezen a területen fejlődött a leglátványosabban. Muszáj megjegyezni, hogy Dénes és a többi kutató is zömében a labdarúgó csapatok példáján határozta meg a merchandising jogok piacát, de a „csecse-becse” piac nyomokban más sportágaknál - legyen az egyéni vagy csapat - is fellelhető.

A valóban üzleti alapon működő futballvállalatoknál András (2004) szerint, a merchandising bevételek komoly jövedelemforrást jelentenek. A merchandising tevékenység kiegészítő reklámtevékenységet erősítheti a fogyasztói elkötelezettséget, fokozhatja a végső fogyasztók keresletét. András (2004) leírta, hogy a 2003 nyarán - a MSzH munkatársai segítségével - elvégzett kutatás kiterjedt a magyar futballtársaságok lajstromba vételének állapotára. Ennek eredménye alapján elmondható, hogy a magyar labdarúgó-vállalatok jellemzően még jogi értelemben sem biztosítják márkáik kiépítését, és az erre épülő merchandising tevékenységet. A szurkolói hűség sokkal erősebb kötődést jelent a márkahűségnél, ezért egy esetleges minőségromlás, vagy a piacon megjelenő, jobb minőségű és ugyanolyan könnyen elérhető versenytárs (például egy másik, sikeresebb helyi klub) megjelenése sem eredményez a fogyasztók többségénél „márkaváltást”. A fogyasztók hűségük kifejezéseként merchandise termékeket, magyarul „csecse-becséket” is rendszeresen vásárolnak.[53]

Itthon szembetűnő probléma, hogy sem a tornában, sem a cselgáncsban, sem az öttusában, sem a birkózásban sem pedig a kajak-kenuban nem történtek olyan mértékű fejlesztések, hogy egy-egy sporteseményre tömegeket lehessen bevonzani. Vannak törekvések arra, hogy Magyarország világversenyeket rendezzen ezekben a sportágakban, de ezek csak egyszeri kiugró nézőszámot produkálnak. Mivel kevesebbszer szerepel a médiában az adott sportág, így a sportszponzorálási piacon alul marad a többször TV képernyőre kerülő sportágakkal szemben. Az egészséges verseny feltételei sajnos nem adottak. Ugyan ezen sportágak médiaképessége folyamatosan növekszik, de kérdés hogy ez csak a több sportcsatornának köszönhető, vagy annak, hogy az emberek körében népszerűbb a sport, és nem csak négyévente szeretnék a sikeres sportolókat versenyezni. Egyéni sportágakban a játékospiac elenyésző, hiszen minden sportolónak az egyéni sportszakmai siker a legfontosabb. A felkészülést és versenyzési tervet az olimpiai szereplés mozgatja, és a kontinensbajnokságok mellett az olimpiai arany a motiváló tényező. Nincs csapatokon és földrészeken átívelő csapatváltás, hiszen itt a nemzeti identitástudat az első számú szempont, és ha vannak is különböző csapatversenyek úgynevezett ligák, azok is a különböző világversenyek és kvalifikáló viadalok közé vannak beszúrva, hogy ne zavarják meg a kialakult rendszert. Természetesen ezek a ligaversenyek jók a sportolóknak, hiszen a holtidőben is megmérkőzhetnek magas kvalitású társaikkal, és emellett még pénzt is kereshetnek, ami jelen esetben a motivációs tényezőt jelenti. A mercahndising piacról megállapítható, hogy ugyan jelen van és nyomokban megtalálható az egyéni sportágakban is, de nyugodtan kijelenthető, hogy gyakorlatilag nem létezik, mert olyan elenyésző bevételt produkál, ami miatt nem válhat meghatározó tényezővé. 
Jelen esetben a kérdést úgy tehetjük fel, hogy az egyéni sportok fel tudjá-e venni a versenyt a többi olimpiai, vagy nem olimpiai sportággal? Vizsgálatomban a versenyképességet a sportág médiában elfoglalt szerepe alapján vizsgáltam, hiszen a Nemzetközi Olimpiai Bizottság (NOB), illetve az aktuális nyári játékok szervezőbizottsága (OCOG) is így tesz, azaz minél nagyobb a nézőszám egy-egy sportág esetében, annál nagyobb lesz a támogatási összeg, amelyet a sportágnak juttatnak. E cikkben azt vizsgáltam meg, hogy a 2012-es nyári játékokon milyen mértékben volt jelen a sportág a médiában, mennyire volt versenyképes a nézőkért folytatott harcban.

\section{Az egyes sportágak versenyképességének jellemzése}

A 3. táblázatot a Londoni olimpia szervezőbizottsága, a LOCOG és a Nemzetközi Olimpiai Bizottság (NOB) adatai alapján szerkesztettem, mely az egyes olimpiai sportágak média értékük szerinti csoportosítását mutatja.A táblázat a sportágak médiában való megjelenése alapján készült, a helyszínen való részvételt nem tartalmazza. Fontosságuk szerint $\mathrm{ABC}$ kategóriákba sorolták a sportágakat, ahol az A csoport a legtámogatottabb, míg az E egy újonnan létrehozott csoportot jelent, ahol egyelőre nem beszélhetünk támogatási összegről. Ebben a csoportban szereplő sportágak támogatásának mértéke a 2016. évi Rio De Janeiro-i olimpiai játékok után, a nézettségi adatainak tükrében kerül elosztásra. Tehát a sportágak versenyképessége hogyan azonosítható be? Hazánkban eltartóképes-e a sportág, vagy esetleg rosszabb? Mivel a sportágban hazai sikerekről beszélhetünk, a kormányzat támogatását élvezi a szövetség.

A táblázat alapján láthatjuk, hogy a birkózás a „D” jelû csoportban szerepel, tehát nem tartozik a legnézettebb sportágak közé. A fő problémát az jelenti, hogy a bevezetett szabálymódosítások vitatottak, a laikus nézők számára nem vagy nehezen érthetőek. A 2012-es ötkarikás játékok után a birkózás nagyon nehéz helyzetbe került az olimpiai szereplés tekintetében. A Nemzetközi Olimpiai Bizottság (NOB) döntése alapján a sportág léte lett megkérdőjelezve, hiszen felmerült, hogy 2020-tól a szakág kimaradhat az olimpiai programból. A NOB ezt a döntést azon saját 39-es kritériumrendszere alapján tette meg, ami figyelemmel van a játékok gazdasági és üzleti vonatkozásaira is, nem csupán a hagyományokra. Többek között értékelik az adott sportág helyszíni nézőszámát, a globalizáltságát, illetve a médiában való nézettségét, továbbá a doppingellenes rendszerét is. Érdemes megjegyezni, hogy egy-egy olimpián pontosan meghatározott a sportágak lebonyolítási sorrendje, a résztvevő versenyzők, illetve a kiosztható érmek száma is.

A NOB korlátozni kényszerült e keretszámokat, így alapos vizsgálat alá vetették a jelenlegi olimpiai sportágakat, hogy hol lehetne alakítani az ötkarikás programban. Ez a kényszer, illetve az új, jelenleg még nem olimpiai sportágak erősödése késztette arra a bizottságot, hogy pellengérre állítsák a birkózást. A 2016-os riói olimpiára felvett rögbi és golf nem lehetett kieső, így 26 sportág közül kellett egyet kiválasztaniuk a tagoknak. „Nemcsak sportszakmailag kell világszínvonalat nyújtani, hanem kapcsoltan szükséges a népszerűség, a stabilitás, nagy nézettség és a tradíciók is".[7] Napjainkban már a NOB is rákényszerül az üzleti gondolkozásra és az üzleti szféra igényeinek való megfelelésre. Kénytelen volt rövid idő alatt olyan sportágaknak is komoly bevételt generálni, melyek vagy a médiaképességük gyengesége, vagy az intézményi rendszerük gondolkodásából hiányzó üzleti szemlélete miatt szinte csak abból élnek, hogy az olimpián szerepelnek. András (2013) szerint a 
birkózásnak fogyasztói piaca szinte csak az olimpiák vonatkozásában értelmezhető, adásvétellel jellemezhető sportolói piaca nincsen. A sportmerchandise piac egyáltalán nem létezik, pedig ennek a lenne a feladata a nézői elkötelezettség kialakítása és megszilárdítása.

\begin{tabular}{|l|l|l|}
\hline Csoportosítás & Sportágak & Támogatási összeg \\
\hline A & Atlétika, Torna, Vízi sportok & 47 millió USD \\
\hline B & $\begin{array}{l}\text { Kosárlabda, Kerékpár, Labdarúgás, Tenisz, } \\
\text { Röplabda }\end{array}$ & 22 millió USD \\
\hline C & $\begin{array}{l}\text { Ijászat, Tollaslabda, Ökölvívás, Cselgáncs, } \\
\text { Evezés, Sportlövészet, Asztalitenisz, Súlyemelés }\end{array}$ & 16 millió USD \\
\hline D & $\begin{array}{l}\text { Kajak-kenu, Vívás, Kézilabda, Birkózás, } \\
\text { Lovaglás, Vitorlázás, Taekwondo, Triatlon, } \\
\text { Gyeplabda 14 millió USD }\end{array}$ & \\
\hline E & Öttusa, Golf, Hetes Rögbi & Újonnan létrehozott csoport \\
\hline
\end{tabular}

(Forrás: Saját szerkesztés a LOCOG, NOB adatai alapján, 2015)

Szintén a „D” kategóriában található akajak-kenu is. Talán nem elég látványos a sportág? Szükséges a változás? 2019-ben Magyarország rendezheti a sportág világbajnokságát. Szeged pályázata felismerte a hiányosságokat a TV közvetítések terén. A nyertes program számos területen tér ki a látványosságot növelő tényezőkre. A rendezők 4K felbontás bevezetésével és drón kamerák alkalmazásával kívánják megreformálni az eddigi média megjelenések egyhangúságát. Ezeknek az új eszközöknek a használata hihetetlen látványos felvételeket készíthet a sportolókról, egészen közelről követhetjük az eseményeket, szinte a nézők is a hajókban ülhetnek. A nézettség és a fenntarthatóság növelése a cél, hiszen ez jelentheti a sportág jövőjét.Bár nemzetközi támogatás tekintetében jelenleg a kajak-kenu a 4. csoportban található, de a technikai fejlődés hatására a sportág látványosabb, szórakoztatóbb módon jelenhet meg mint eddig, ami abba az irányba mozdíthatja el a sportág helyzetét, hogy egy biztonságosabb illetve nagyobb támogatást jelentő csoportba kerülhet. Ezáltal több néző követheti az eseményeket a médián keresztül, aminek köszönhetően egyre több támogató és szponzor jelenik majd meg a sportágon belül. Ez számunkra azért is fontos, mert egy hagyományosan magyar sikereket hozó olimpiai sportágról beszélhetünk, amit mindenáron a nyári olimpiai játékok programjában kell maradnia.

Nézettségi szempontból az öttusa sportág található a legkedvezőtlenebbkategóriában. A Londoni Olimpián a sportágak nézettségi listáján az utolsó „E” kategóriában található. Nézettségének javítása érdekében 2009-ben már történtek intézkedések. Szabálymódosítással próbálták a szabályozók rövidebbé és látványosabbá tenni az öttusa versenyeket. Eredményeképpen a futás és a lövészet a téli olimpián szereplő biathlon sportághoz hasonlóan egyszerre történik. A versenyzők „handicap” rendszerben rajtolnak. Nagyjából 20 méter futás után 5 lövést kell leadniuk, legfeljebb 1 perc 10 másodperc alatt. Utána 1000 méter futás következik, ami után ismét 5 alkalommal lőnek. A versenyzőknek ismételten legfeljebb 1 perc 10 másodperc áll rendelkezésükre. Újabb 1000 méter 
futás és 5 lövés leadása után, amelynek szintén a korábban említett időhatár a korlátja, újabb 1000 méter futással zárul a verseny.

A táblázat alapján láthatjuk, hogy a cselgáncs a „C” jelű csoportban szerepel, tehát nem tartozik a legnézettebb sportágak közé, azonban más egyéni sikersportágunk sokkal inkább veszélyeztetetebb helyzetben található. Az elmúlt 10 évben a cselgáncs drasztikus változásokon ment keresztül mind sportszakmai, mind pedig sportgazdasági oldalról nézve is. Alap mozgásformákat töröltek el a sportolóktól, hogy látványosabbá tegyék a küzdelmeket, illetve annak érdekben, hogy gyorsabban véget érjen egy-egy versenynap, megváltoztatták azok lebonyolítási rendszerét. Ezeknek a lépéseknek köszönhetően látványosabbá, eladhatóbbá, ezáltal versenyképesebbé vált a sportág. Az olimpián az jelenti az igazán nagy fegyvertényt, hogy egységnyi idő alatt hány emberhez jutott el a sportág, hány nézőt volt képes kiszolgálni a sportesemény. Ez főleg amiatt van így, mert közvetítési jogokról szinte csak az olimpiák kapcsán beszélhetünk. Persze mivel a világ legnépszerűbb küzdősportjáról beszélünk, a több mint 40 millió sportoló világszerte is kedvezően hat a nézettségi adatokra.

\section{A sportágak jövője Magyarországon, következtetések}

Egy sportág jövője mindig is nagyban függött az állami támogatások mértékétől.[15] 2019-ben Magyarország rendezheti a kajak-kenu világbajnokságot. Szeged pályázata felismerte a hiányosságokat a TV közvetítések terén. A nyertes program számos területen tér ki a látványosságot növelő tényezőkre. A rendezők $4 \mathrm{~K}$ felbontás bevezetésével és drón kamerák alkalmazásával kívánják megreformálni az eddigi médiamegjelenések egyhangúságát. Ezeknek az új eszközöknek a használata hihetetlen látványos felvételeket készíthet a sportolókról, egészen közelről követhetjük az eseményeket, szinte a nézők is a hajókban ülhetnek. A nézettség és a fenntarthatóság növelése a cél, hiszen ez jelentheti a sportág jövőjét. Bár nemzetközi támogatás tekintetében jelenleg a kajak-kenu a 4. csoportban található, de a technikai fejlődés hatására a sportág látványosabb, szórakoztatóbb módon jelenhet meg mint eddig, ami abba az irányba mozdíthatja el a sportág helyzetét, hogy egy biztonságosabb illetve nagyobb támogatást jelentő csoportba kerülhet. Ezáltal több néző követheti az eseményeket a médián keresztül, aminek köszönhetően egyre több támogató és szponzor jelenik majd meg a sportágon belül. Ez számunkra azért is fontos, mert egy hagyományosan magyar sikereket hozó olimpiai sportágról beszélhetünk, amit mindenáron a nyári olimpiai játékok programjában kell maradnia. A sportág létesítményhelyzete hiányos, de ez elmondható a vizsgált sportágakról is. A tervezett világbajnokság miatt a Szeged-i olimpiai centrum fejlesztések előtt áll, de a korábban említett főbb városok sportléesítményeit is újítani, bővíteni kéne a jobb körülmények érdekében. Az egyesületek létesítnényeinek vonzóbbá tétele, az utánpótlásbázis növelésében alapvető szempont lehet.

Az öttusa szövetség stratégiai céljainak megformálása során alapvető szempont volt a sportág alapjainak szélesítése, az úszó-futó versenyen résztvevő versenyzők számának megháromszorozásán keresztül. A szervezet nagy hangsúlyt kíván fektetni új az utánpótlásbázis fejlesztésére. Egészen a kisiskolás kortól kezdve, évente legalább 5000 gyermek számára kölyök öttusa esemény szervezése a cél. A MÖSZ által kiadott stratégiai terv (sportági stratégiai terv 2013) szerint a szövetség képviselői a sportolói létszám növelésével szoros összefüggésben tervezik a meglévő egyesületek erősítését, és az 
azokban jelen lévő edzésfeltételek javítását. A létesítményfejlesztés kiemelt szerepet jelent, hiszen egy új öttusa központ kialakítása (mind az öt szám egy helyszínen, mely világverseny rendezésére is alkalmas) jelentősen csökkentené a szövetség szervezési és fenntartási költségeit. A szövetség helyzetének megerősítése jelentős szerepet tölt be az öttusa stratégiájában. Bővíteni kívánják a személyi állományt is. Úgy gondolják, hogy ezzel a lépéssel a proaktív programok menedzselés képességének javulása várható. A hazai versenyrendezés feltételeinek javítása, az imidzs és a látványvilág javítása elengedhetetlen, hiszen a versenyek „élményszintjének” emelése révén több sporteseményt rendezhet a szövetség, mely által egyre több néző ismerkedhet meg a sportággal. Fontosnak tartják a magas szintű versenyzők kettős karrier lehetőségeinek szélesítését, melyet különböző ösztöndíj programok segítségével kívánnak megvalósítani.

Ezzel a tervvel kapcsolatban a cselgáncs szövetség képviselőivel partneri kapcsolatot lehetne kialakítani, hiszen a Magyar Judo Szövetség elkötelezett híve a sport utáni sikeres civil életnek. A kettős karrier programmal itt is találkozhatunk. A cél az lenne, hogy a versenyzők a sportkarrierjük mellett is egyetemen vagy főiskolán tanuljanak. A hazai szabályozók úgy gondolják, hogy amíg ezek a sportolók iskolába járnak, addig kell megteremteni a sporttól független civil szférában való elhelyezkedésüket. Ezt szolgálja az Életút Program nevü kezdeményezés. Ahhoz, hogy a kiöregedett vagy esetleg egy komolyabb sérülés miatt visszavonuló sportolók a civil életben hasznos szakképesítést kapjanak, hogy a sportolás abbahagyása után is értékes tagjai legyenek a társadalomnak. Természetesen a létesítményhelyzet itt is nagyon nehéz kérdés. A magyar cselgáncs sportban önálló létesítményekkel, csak a kiemelkedő felnőtt és utánpótlás eredményt felmutató szakosztályok rendelkeznek. A szakosztályok többsége csarnokokban, iskolai tornatermekben, bérleti díj fizetése ellenében, korlátozott óraszámban kénytelen megoldani és ellátni a feladatát. A rendszeres - hetente - történő válogatott keretedzéseket különböző fóvárosi kluboknál (BHSE, UTE, KSI SE) oldják meg, nem megfelelő feltételek között. Jelentős gondot okoz, hogy a MJSZ sportlétesítmény használatáért 2012-ben mintegy 2,5m Ft-ot fizetett ki. Saját elmondásuk szerint, szükségük lenne Budapesten egy önálló multifunkcionális edző és versenycsarnok létrehozására, amely állandó tatami felülettel rendelkezik, és a hét minden napján használható. Összességében elmondhatjuk, hogy rengeteg hasonlóság van a vizsgált sportágak helyzetében.

Sem a birkózás sem pedig a többi sportág nem tartozik azon sportágak közé, melyek a médiából befolyt összegekből el tudják tartani magukat. Jelen esetben nem beszélhetünk a félidők közötti reklámbevételek szétosztásáról, hiszen a szponzoráció nagyon alacsony mértékben van jelen a szakágban. Általánosságban elmondhatjuk, hogy a Magyar Olimpiai Bizottság és az Emberi Erőforrások Minisztériuma jelenti a két legnagyobb támogatót a sportágaknál. Mivel a Magyar Birkózó Szövetség a működéséhez szükséges bevételeit döntő többségben az államháztartás más alrendszerétől kapja, fontos az eredményességet megőrizni. Ez az eredménykényszer természetesen a jelenlegi kutatásban vizsgált sportágakra is igaz. A szervezet céljai között szintén kiemelt helyzetben van az utánpótlás bázis fejlesztése. A birkózás központi edzőközpontot hozott létre, ahol a sportdiplomáciai helyzetüket felhasználva a környező országok sportolóival közösen szerveznek edzéseket. Ez a központi edzéslehetőség lehet a kulcsa a további fejlődésnek. 
Általánosságban elmondható, hogy a hazai létesítményhelyzet nem kielégítő. Nehéz vonzóvá vállnia egy sportágnak rosszul felszerelt edzőközpontokkal,és ez nagyban megnehezíti az utánpótlás fejlesztését. Ennek ellenére azonban a vizsgált sportágak stratégiai fejlesztésinek köszönhetően az igazolt sportolói létszámok növekedést mutatnak, amely üdvözítő a jövőre nézve. A vizsgált szakágak a támogatást zömében a kormányzattól kapják, amely egy magasszintű teljesítménykényszert eredményez. Nem szabad azonban elfelejteni, hogy ezt nagy többségben a legutolsó de mégis a legfontosabb láncszem, maga a sportoló szenvedi meg igazán. Ahhoz, hogy ez ne kényszer legyen szükséges lenne a szövetségeknek egyéb bevételi források során - különböző pályázatok - pénzhez jutni. A hazai szövetségek a nemzetközi sportági szabályozók döntései alapján tudnak szabályokat vagy lebonyolítási rendet változtatni, így a médiaképesség növelése érdekében nehéz helyzetben vannak. Az utóbbi években hazánkban is nőtt a sportcsatornák száma, így a nézők többször találkozhatnak a kevésbé médiaképes sportokkal is. Ez nagy előny a szakágaknak, hiszen így nem csak négyévente szerepelnek a sportolók és a sportágaik a médiában. A cél az lenne, hogy minél több hazai és nemzetközi sporteseménynek legyen médiavisszhangja, ismerjék meg a sportágat és azokat a sportolókat, amelyek potenciálisan éremesélyesek az ötkarikás játékokon. Ha minél több ember találkozik a sportággal, annál többen fogják követni a sporteseményeket, közvetítéseket, ezáltal sokkal nagyobb a valószínűsége, hogy növekedni fog a sportágak marketing értéke. A régi szponzorok megtartása mellett óriási feladatot jelent az új támogatók bevonása a sportiparágba, és ez csakis megfelelő mennyiségű néző bevonásával érhető el.

\section{Hivatkozások}

[1] K. András, M. Kozma, Z. Kynsburg, Á. Rohony (2000), Üzleti elemek a labdarúgásban, ISMkutatás (812-11 futballmenedzsment), zárótanulmány, Budapest

[1] K. András (2013), A sport és az üzlet kapcsolata - elméleti alapok, 34. sz. Múhelytanulmány,BCE Vállalatgazdaságtan Tanszék, Budapest

[2] K. András (2004), A hivatásos labdarúgás piacai, Vezetéstudomány, XXXV. évfolyam, PhD különszám, 40-57. o. 2004.

[3] K. András (2006), A szabadidősport gazdaságtana, 75. sz. Műhelytanulmány HU ISSN 1786-3031.

[4] K. András (2011), A hivatásos labdarúgás múködési modellje, Magyar Sportudományi Füzetek III. - Sportágak versenye, 18-42. o.

[5] K. András, Z. Jandó (2012), Hivatásos sportvállalatok nemzetközivé válása, Logisztikai híradó, márciusi különszám, 42-47. o. András K. - Havran Zs. (2014): Regional exportefficiency on the market of football players. Conference Paper, submitted for review, Competitivess of the CEE Region in the Global Economy, October 8-10 2014., Budapest

[6] K. András, A birkózás irányítói is felelösek, ha kikerül a sportág az olimpiáról, http://www.vg.hu/kozelet/tarsadalom/a-birkozas-iranyitoi-is-felelosek-ha-kikerul-asportag-az-olimpiarol-399532 Letöltés időpontja: 2015.11.23. 16:43 
[7] K. András, M. Kozma (2014), A nagy nemzetközi sportesemények gazdasági hatásai, Budapest

[8] W. Andreff (2008), Globalization of the sports economy, Rivisita di diritto ed economia dello sport Vol. IV.

[9] P. Ács (2007), A magyar sport területi versenyképességének vizsgálata többváltozós statisztikai módszerekkel, Tér és Társadalom 21. évf. 2007/2.117-126. p.

[10] A. Bakács (2004), Versenyképesség koncepciók, A Gazdasági és Közlekedési Minisztériu által finanszírozott, "A hazai közlekedési hálózatok hatékonysága, versenyképessége növelésének lehetőségei a nemzetközi tapasztalatok alapján" (röviden HAVER-) címú kutatási projekt keretében készült tanulmány (kutatásvezető: FLEISCHER T.). 2003. november 9. MTA Világgazdasági Kutat Intézet, Budapest. 24 p.

[11] L. Balogh (2014), Sportinnováció, „Innovációs lehetőségek a sporttudományok területén” TÁMOP-4.1.2.E-13/1/KONV-2013-0011.

[12] M. Bató (2003), AZ Európai Unió versenyképessége, PhD értekezés. Budapesti Corvinus Egyetem Nemzetközi Kapcsolatok PH.D. Program, Budapest. 186 p.

[13] É. Bácsné Bába (2015), Sportszervezetek múködési kereteinek változása, KÖZÉP-EURÓPAI KÖZLEMÉNYEK (No. 28) VIII. évf.:(1.) pp. 151-161.

[14] P. Becsky-Nagy P., T. Dékán, R. Szőke, Z. Bács (2015), The relevance of sports financing, APSTRACT 2015/1. pp 19-22. 2015.

[15] A. Bencsik, T. Juhász, R. Machora (2014), Mentor system/practiceonthe behalf of knowledge sharing, Acta Politechnika Hungarica 2014/Vol. 11. No. 9. pp 95-114. ISSN 1785-8860. 2014.

[16] P. Berkes (2013), Marketingorientációs tényezók a honi professzionális labdarúgás szponzorációs piacának tükrében, Doktori értekezés - Nevelés- és Sporttudomány Doktori Iskola

[17] J-F. Bourg (2000), Analyseéconomique du Sport

[18] A. Chikán, E. Czakó (2002), Kis nemzetgazdaságok versenyképessége a globális gazdaságban - a magyarpélda. - Chikán A.-Czakó E.-Zoltayné Paprika Z. (szerk.) Vállalati versenyképesség a globalizálódó magyar gazdaságban. Alcadémiai Kiadó, Budapest. 27-39. o.

[19] A. Chikán, E. Czakó (szerk.) (2009), Versenyben a világgal - Vállalataink versenyképessége az új évezred küszöbén, Akadémia Kiadó, Budapest

[20] A. Chikán (2006), A vállalati versenyképesség mérése, Pénzügyi Szemle, Volume 51, No. 1, 42-57. o

[21] A. Chikán (2008), Vállalatgazdaságtan, AULA Kiadó, 4. átdolgozott, bővített kiadás. Budapest 
[22] M. Csath (2010), Versenyképesség-menedzsment, Nemzeti Tankönyvkiadó, ISBN: 9789631968453

[23] E. Czakó (2010), Versenyképesség iparágak szintjén - a globalizáció tükrében, PhD disszertáció, BKÁE. Budapest. 2010.

[24] F. Dénes (1998), A futball eladásának közgazdasági alapjai, Marketing\&Menedzsment 1998/5, pp.59-63.

[25] L. Gallovits, L. Honfi, Gy. Széles-Kovács (2011), Sport A-tól Z-ig. Általános és különleges sportágak ismerete, Pécsi Tudományegyetem, Szegedi Tudományegyetem, NyugatMagyarországi Egyetem, Eszterházy Károly Főiskola, Dialóg Campus Kiadó-Nordex Kft.

[26] T. Gyömörei (2012), Hungarian Sports Structures: Competitiveness of University Sport, In: 8th Annual International Bata Conference for $\mathrm{PhD}$ students and young researchers Conference (Csehország, Zlin)Kozma M. - Kynsburg Z. (2000): A játékosok menedzsmentje, in: András K. - Kozma M. - Kynsburg Z. - Rohony Á. (2000): Üzleti elemek a labdarúgásban, ISM-kutatás (812-11 futballmenedzsment), zárótanulmány, Budapest. 2012.

[27] L. Kassay (1998), A szponzorok és reklámozók kiszolgálása, Marketing\&Menedzsment 1998/3, pp.25-27.

[28] M. Kozma, Ó. A. Kazainé (2013), Measuring Business Performance in Sports - How the Balanced ScoreCard approach can help sports organisations in operating along strategic objectives, Proceedings of International Conference on Economics and Business Management, 2013. november 23., Kolozsvár, Románia

[29] I. Lengyel (2000), A regionális versenyképességról, Közgazdasági Szemle, XLVII. évf., 2000. december 970. p.

[30] I. Lengyel (2000), Porter-rombusz: a regionális gazdaságfejlesztési stratégiák alapmodellje, Tér és Társadalom, XIV. évf., 39-86. o.

[31] T. Madarász (2013), A cselgáncs sportág általános bemutatása, szabálymódositásainak megismertetése és ezek gazdasági hatásainak az elemzése, MsC diplomadolgozat, Semmelweis Egyetem Testnevelés és Sporttudományi Kar, Budapesti Corvinus Egyetem Gazdálkodástudományi Kar. Budapest

[32] T. Madarász (2015), Támogatási lehetőségek a csapatsportágak vs. egyéni sportágak esetében, a TAO sportágak sportgazdasági helyzetének áttekintése a támogatói oldalról, Debrecen

[33] Magyar Birkózó Szövetség sportágfejlesztési stratégia 2013-2020

[34] Magyar Birkózó Szövetség 2014. évi Egyszerüsített Éves Beszámoló Kiegészítő Melléklete és Közhasznúsági Jelentése

[35] Magyar Cselgáncs Szövetség sportágfejlesztési stratégiája 2013-2020 
[36] Magyar Kajak-kenu Szövetség sportágfejlesztési stratégiája 2013-2020

[37] Magyar Öttusa Szövetség sportágfejlesztési stratégiája 2013-2020

[38] T. Misovicz (1997), Mi megy a tévében? A sportmúsorok átváltozása, Jel-Kép 1997/1. szám, pp. 23-33.

[39] I. Z. Nagy, É. Bácsné Bába (2014), Szervezeti átalakulások futballvállalkozásoknál, AGRÁRTUDOMÁNYI KÖZLEMÉNYEK, ACTA AGRARIA DEBRECENIENSIS 2014:(58) pp. 141-146.

[40] I. Z. Nagy, É. Bácsné Bába (2014), OrganizationalChanges of Professional Football Companies, JOURNAL ON LEGAL AND ECONOMIC ISSUES OF CENTRAL EUROPE 5.:(2.) pp. 102-111.

[41] Z. B. Nagy, G. Tóth, I. Sárközi, L. B. Kiss (2014), Együttmúködés és/vagy versengés: a versenyképesség határai az élsport és a tömegsport színterein, Pannon Egyetem, cop.

[42] G. A. Némethné (2010), A kis- és középvállalatok versenyképessége, Közgazdasági Szemle, LVII. évf., 2010. február (181-193. o.).

[43] D. Paár (2013), A magyar háztartások sportfogyasztásának gazdasági szempontú vizsgálata, Doktori (PhD) értekezés, Nyugat-magyarországi Egyetem

[44] É. Palócz (2006), Egészségügy és versenyképesség; Tanulmány, Kopint-Datorg Rt., Budapest

[45] N. Potori (2014), A fóbb mezőgazdasági ágazatok élet- és versenyképességének követelményei, Agrárgazdasági Kutató Intézet, Budapest. 91 p. 2014.(HU ISSN 14182122 ISBN 963491472 1)

[46] T. Sárközy (2002), A sporttörvény magyarázata, Budapest, HVGOracLap- és Könyvkiadó Kft.

[47] M. J. Sirgy (1982), Self-concept in consumer behavior: a critical review, Journal of consumer research, 287-300.

[48] T. Sterbenz (2011), Miért nem gömbölyü? Sportágak versenye, Magyar Sporttudományi Füzetek III., Budapest

[49] T. Sterbenz, E. Gulyás (2013), A lyukas piramis, in. Sterbenz Tamás - Szőts Gábor (szerk. 2013): Verseny-pályán MSTT-füzetek IX. 121-132. Budapest

[50] Á. Urbán (1997), Sportüzlet, média és társadalom, Jel-Kép, 1997/1., pp. 15-22. Budapest

[51] Á. Urbán (1998), Sport és média - A sportmédia iparági szintű és szolgáltatás jellegü elemzése, BKE diplomadolgozat. Budapest

[52] Á. Szabó (2009), A (szabadidó)sport alapfogalmai és kutatott területei, BCE Műhelytanulmány, Vállalatgazdaságtan Intézet, p. 1-36. Budapest

[53] Á. Szabó (2012), A magyar szabadidősport működésének vizsgálata, Piacok, értékteremtés, feladatok a szabadidősportban. Budapest 
International Journal of Engineering and Management Sciences (IJEMS) Vol. 1. (2016). No. 1.

DOI: 10.21791/IJEMS.2016.1.31.

[54] G. Whannel (1992), Fields in Vision, Routledge, London, idézi: Urbán Á. (1997): Sportüzlet, média és társadalom, Jel-Kép, 1997/1., pp. 15-22.

[55] 1526/2013. (VIII. 12.) Korm. Határozat

[56] 2004. évi I. törvény - a sportról

[57] 2011 évi LXXXII törvény a sport támogatásával összefüggő egyes törvények módosításáról 